\title{
The role of chronobiology and circadian rhythms in type 2 diabetes mellitus: implications for management of diabetes
}

This article was published in the following Dove Press journal:

ChronoPhysiology and Therapy

29 July 2014

Number of times this article has been viewed

\section{Takeshi Kurose \\ Takanori Hyo \\ Daisuke Yabe \\ Yutaka Seino}

Center for Diabetes, Endocrinology and Metabolism, Kansai

Electric Power Hospital,

Fukushima, Osaka, Japan
Correspondence: Takeshi Kurose Center for Diabetes, Endocrinology and Metabolism, Kansai Electric Power Hospital, 553-0003, 2-I-7 Fukushima, Fukushima Ward, Osaka, Japan Email kurose.takeshi@b4.kepco.co.jp

\begin{abstract}
Circadian clocks regulate cellular to organic and individual behavior levels of all organisms. Almost all cells in animals have self-sustained clocks entrained by environmental signals. Recent progress in genetic research has included identification of clock genes whose disruption causes metabolic abnormalities such as diabetes, obesity, and hyperlipidemia. Here we review recent advances in research on circadian disruption, shift work, altered eating behaviors, and disrupted sleep-wake cycles, with reference to management of type 2 diabetes.
\end{abstract}

Keywords: diabetes, clock gene, shift work, eating behavior, sleep loss

\section{Introduction}

Circadian rhythms of physiological functions have been shown to be regulated by endogenous molecular oscillators called circadian clocks. The master circadian clock resides in the suprachiasmatic nucleus (SCN) as a central regulator of the peripheral clock system, and is entrained directly by light. ${ }^{1,2}$ Circadian clocks in peripheral cells are regulated by SCN via body temperature, humoral signals, and feeding in addition to light. The main mechanism of the molecular clock is composed of transcriptionally and translationally regulated feedback loop systems. Transcriptional activation by brain and muscle Arnt-like protein (BMAL1) and circadian locomotor output cycles kaput (CLOCK) up-regulate negative elements of Period (Per1, Per2, and Per3) and cryptochrome (Cry1 and Cry2) genes. Accumulation of Per and Cry proteins inhibit BMAL1/CLOCK activity (Figure 1). The expression cycle of clock genes forms an approximate 24-hour cycle. The second feedback loop involves the retinoic acid-related orphan receptor (ROR) $(\alpha, \beta$, and $\gamma$ ) and REV-ERB (an orphan receptor encoded on the noncoding strand of the thyroid alpha gene) ( $\alpha$ and $\beta$ ) proteins, members of a subfamily of nuclear receptor that recognizes cis-regulatory elements (ROREs) of target genes. RORs act as transcriptional activators and REV-ERBs are repressors. The BMAL1/ CLOCK binds to E-box elements present in Ror and Rev-erb genes and activates their transcription. ${ }^{3}$ RORs and REV-ERBs in turn control rhythmic transcription of the BMAL1 gene. ${ }^{4,5}$

Recent progress in basic research on circadian rhythms and metabolism has yielded discoveries of O-linked beta-D-N-acetylglucosamine (O-GlcNAc) signaling, ${ }^{6}$ nicotinamide adenine dinucleotide (NAD+)-dependent sensors, ${ }^{7,8}$ nicotinamide phosphoribosyltransferase (NAMPT), ${ }^{9,10}$ silent mating type information regulation 2 homolog 1 (SIRT1), ${ }^{11,12}$ peroxisome proliferator-activated receptor gamma co-activator 1-alpha (PGC-1 $\alpha),{ }^{13}$ and $5^{\prime}$-adenosine monophosphate-activated protein kinase 


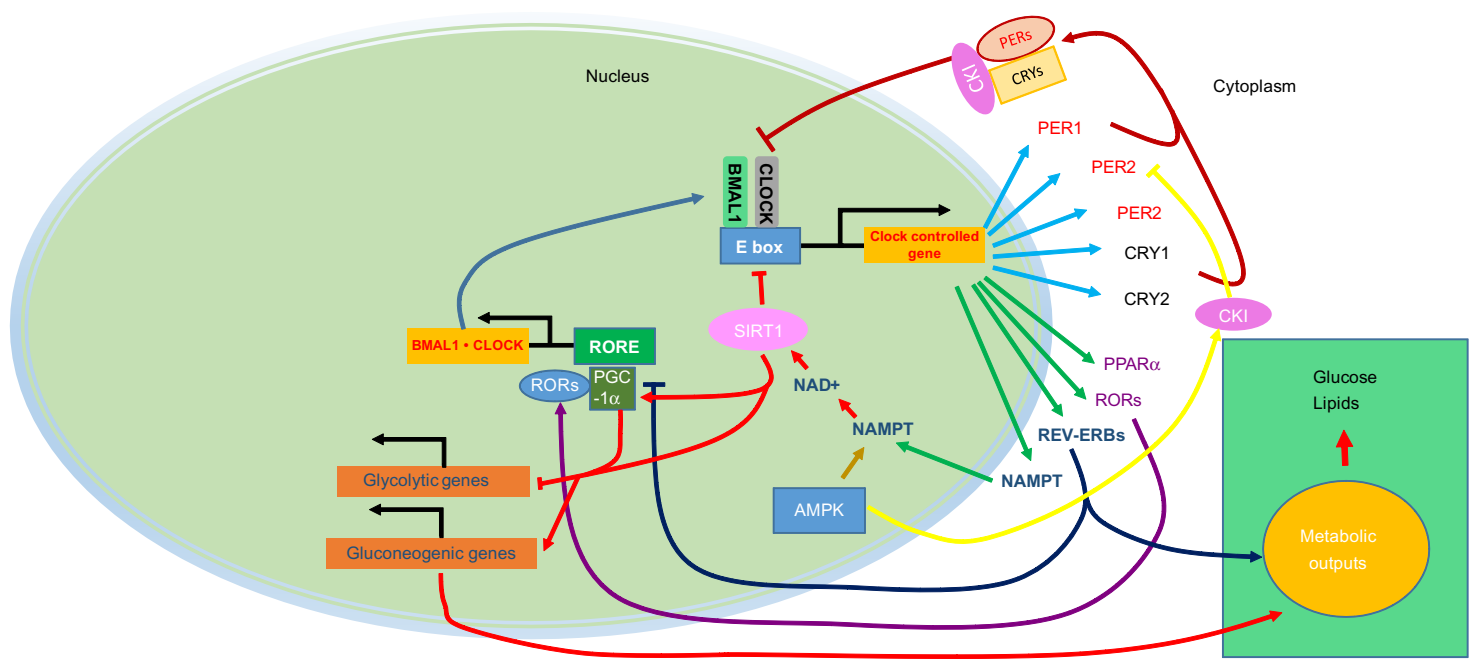

Figure I The mammalian core components of the clock system.

Notes: The circadian clock consists of transcription/translation feedback loops. The positive regulatory components are transcription factors CLOCK and BMALI, which heterodimerize and bind to the E Box of clock target genes and activate downstream genes. These target genes are the period (Per I, 2, and 3), cryptochrome (CRYI and 2), REV-ERB, RORs, and other clock controlled genes.

Abbreviations: AMPK, adenosine monophosphate-activated protein kinase; NAD+, nicotinamide adenine dinucleotide; NAMPT, nicotinamide phosphoribosyltransferase; CKI, casein kinase I; PPAR $\alpha$, peroxisome proliferator-activated receptor alpha; CLOCK, circadian locomotor output cycles kaput; BMALI, brain and muscle Arnt-like protein; PGCI- $\alpha$, peroxisome proliferator-activated receptor gamma co-activator I-alpha.

$(\mathrm{AMPK})^{14}$ as key regulators in circadian systems that link the clock system and metabolism. Due to the large gap between basic and clinical research in this field, fundamental approaches from both directions are appropriate. In this review we discuss management of type 2 diabetes in terms of recent research in chronobiology.

\section{Interaction between peripheral clock function and energy metabolism}

The master central clock in the SCN is primarily entrained by light, and synchronizes peripheral clock components through neural and humoral mechanisms that are still obscure. With regard to glucose metabolism, several metabolic inputs from nutrient sensors operate as molecular clocks in peripheral tissues.

One example is the NAD+-dependent deacetylase SIRT1, an energy sensor with activity dependent on the intracellular NAD+/NADH ratio. Recently, SIRT1 has been thought to be a key regulator of the core clock machinery, since it binds to and inhibits the activity of CLOCK/BMAL1. ${ }^{11,12}$ In addition, SIRT1 is known to play a key role in the regulation of gluconeogenesis, fat metabolism, insulin secretion, and apoptosis through its role in energy generation. ${ }^{15,16}$ Nutrient-dependent regulation of SIRT1 and clock interaction thus regulates many metabolic targets including PGC-1 $\alpha$, peroxisome proliferator-activated receptor alpha (PPAR $\alpha)$ and others. ${ }^{17,8}$ AMPK is another cellular nutrient sensor linked to the clock. AMPK is a stress kinase responding to depleted energy states, which is activated when the AMP-to-ATP ratio increases, causing increased ATP production and decreased ATP utilization. ${ }^{18}$ Exercise also activates AMPK, to restore the energy used. Activation of AMPK by metformin induces PER2 degradation, through casein kinase I epsilon (CKIe), and a phase advance of clock gene expression. ${ }^{14}$ In addition, Lamia et al has identified a consensus motif for phosphorylation by AMPK within CRY protein. Thus, AMPK destabilizes the core clock repressor CRY $1 .^{19}$

Metabolic transcription factors and transcriptional co-activators comprise feedback loops between the core clock and the peripheral tissues. For example, nuclear hormone receptors are ligand-activated transcription factors that regulate gene expression by interacting with specific DNA sequences upstream of their target genes, including REV-ERB $\alpha$, RORs, and PPARs, which demonstrate circadian expression in peripheral tissues. ${ }^{20} \mathrm{REV}$-ERB $\alpha$ regulates gluconeogenesis in hepatocytes, differentiation in adipocytes, and lipid metabolism and also represses BMAL1 transcription. ${ }^{21,22}$ In addition, both $\mathrm{ROR} \alpha$ and PPAR $\alpha$ regulate BMAL1 expression by regulating genes that control lipid metabolism. ${ }^{23,24}$ REV-ERBs and RORs are highly related nuclear receptors, and are often expressed in common tissues such as the liver, adipose tissue, skeletal muscle, and the vasculature. ${ }^{22}$ REV-ERBs have long been considered as true orphan receptors, but heme was identified recently as the ligand for both REV-ERB $\alpha$ and $\beta .{ }^{21,25}$ The synthesis 
of heme is linked to nutritional status through the regulation of delta-aminolevulinate synthase 1 (ALAS1) by the nuclear receptor co-activator PGC- $1 \alpha .{ }^{26}$ This co-activator is induced by fasting and mediates the transition from glucose to fatty acid use as an energy source and has been shown to integrate the mammalian clock and energy metabolism. ${ }^{13}$ As REV-ERB $\alpha$ is involved in the induction of adipogenesis, the known induction of adipocyte differentiation by heme ${ }^{27}$ may also be mediated by this REV-ERB $\alpha$.

Whether the nutrient itself regulates or otherwise affects circadian function is the important issue. There are many candidate nutrient signals entraining cues for peripheral clocks. Among these, glucose is considered to be a particularly potent cue for the clock system. Although the molecular mechanism of the entrainment of the clock system by glucose has been a difficult question, some clues to the answer have been found recently. Li et $\mathrm{al}^{6}$ reported that glucose availability regulates cellular clock oscillation through the hexosamine/O-GlcNAc pathway. In addition, a possible link between fatty acid and circadian function has been postulated. Perturbation of metabolic homeostasis with a high-fat diet can also change the period of locomotor activity rhythm and induce alterations in the expression and cycling of circadian clock genes. ${ }^{28}$

\section{Glucose metabolism and circadian rhythm}

In addition to the major feeding inputs, there are 24-hour highly rhythmic changes in blood glucose levels induced by changes in insulin sensitivity and insulin secretory patterns. ${ }^{29}$ In animal models, insulin release is rhythmically regulated by peripheral pancreatic $\beta$-cell clocks, even in isolated perifused condition. ${ }^{30}$ The 24-hour pulsatile insulin secretion is observed in humans, and has been found to be set at a higher level in obese subjects and in type 2 diabetes patients and their first degree relatives without diabetes. ${ }^{29,31}$ In recent experimental animal studies, global clock mutant mice (Clock $\Delta 19)$ developed age-dependent hyperglycemia and obesity, but showed an inappropriately low concentration of insulin with enhanced insulin sensitivity. ${ }^{32}$ Double Cry1 and Cry2 knockout mice also showed impaired insulin secretion, although their body weight was somewhat less than in control mice, and increased sympathetic tone was observed. ${ }^{33}$ Recently, hyperglycemia induced by ablation of double Cry gene expression was shown to be mediated, at least in part, by hepatic gluconeogenesis due to hepatic over-expression of Cry by lowering blood glucose levels and improving insulin sensitivity in insulin resistant $\mathrm{db} / \mathrm{db}$ mice. ${ }^{34}$
Furthermore, islet specific BMAL1 mutant mice showed normal weight, normal activity, and normal feeding, but significant hyperglycemia with impaired secretion of insulin due to impairment of exocytosis. ${ }^{35}$ In addition, in diabetes-prone rats, disruption of circadian rhythms accelerates development of diabetes through pancreatic $\beta$-cell loss and dysfunction. ${ }^{36}$ Interestingly, a recent in vitro islet study using rat pancreatic islets showed that islets exposed to continuous light were disrupted in circadian clock function, and showed diminished glucose-stimulated insulin secretion due to a decrease in insulin secretory pulse mass. ${ }^{37}$ Accordingly, disruption of circadian rhythm could induce abnormal insulin release in susceptible individuals.

Insulin sensitivity also shows circadian changes, and clock gene disruption induces a lack of rhythmicity in insulin action and activity patterns. ${ }^{38}$ Using hyperinsulinemic-euglycemic clamp, the authors found circadian rhythmicity in insulin action, which was abolished in BMAL1-knockout mice. Most of the counter-regulatory hormones that exert an effect such as anti-insulin, including glucagon, ${ }^{39}$ catecholamine, ${ }^{40}$ and cortisol, ${ }^{41}$ also show circadian rhythm. Growth hormone shows a sleep-related surge that induces early morning insulin resistance. ${ }^{42}$ In addition to these mechanisms, autonomic neural regulation from the hypothalamic SCN exerts effects on the liver. ${ }^{43}$ Thus, insulin sensitivity is under close regulation of circadian control and its impairment has deleterious effects on glucose metabolism.

\section{Timing of food intake and metabolism}

In animal studies, the timing of food intake has been shown to be an important regulator of circadian rhythm and metabolic regulation; there is a strong association of weight gain with circadian timing of food intake. Mice fed a high fat diet only during the 12-hour light phase (corresponding to night-time for humans) gained significantly more weight than mice fed only during the corresponding 12-hour dark phase. ${ }^{44}$ In addition, in mice, consumption of high fat meals at the end of the active phase (corresponding to evening time for humans), leads to increased weight gain, adiposity, glucose intolerance, hyperinsulinemia, hypertriglyceridemia, and hyperleptinemia. Thus, night eating syndrome may promote the risk of obesity and metabolic syndrome. ${ }^{45} \mathrm{Wu}$ et al also reported that the first daily meal determines the peripheral clock phase, whereas the last daily meal tightly couples to lipid metabolism, adipose tissue accumulation, and body weight gain. ${ }^{46}$ 


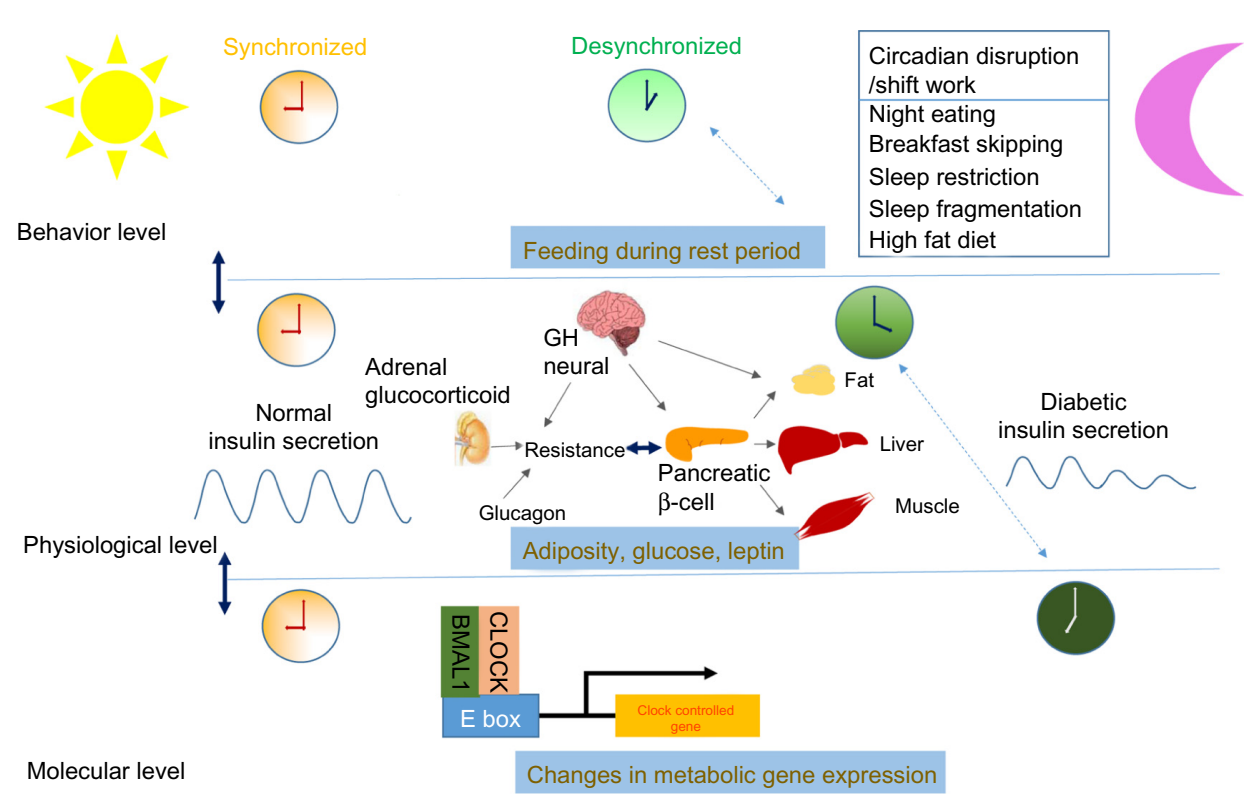

Figure 2 Behavioral factors that may affect the development of type 2 diabetes are influenced by shift work, eating behavior (breakfast skipping, night eating), and sleep loss (sleep restriction, sleep fragmentation).

Notes: These components affect circadian asynchrony. Accumulated evidence suggests that disruption of circadian synchronization between periods of rest and activity with feeding or fasting, and energy storage or energy utilization may be tightly linked to not only obesity, but also glucose metabolism, vascular reactivity, and lipid homeostasis. Reprinted from Cell, I34(5), Green CB, Takahashi JS, Bass J. The meter of metabolism. 728-742, Copyright (C 2008, with permission from Elsevier. ${ }^{75}$

Abbreviations: $\mathrm{GH}$, growth hormone; CLOCK, circadian locomotor output cycles kaput; BMALI, brain and muscle Arnt-like protein.

\section{Circadian rhythms and type 2 diabetes}

The major issue regarding the role of the circadian clock in diabetes is whether disruption of CLOCK or BMAL1 directly leads to metabolic defects or whether the origin is indirectly related to clock function. ${ }^{47,48}$ If disruption of the clock genes or clock mechanisms is directly involved in the development of diabetes, modern life-style itself has an increasingly pathological impact on the development of the disease. In addition to unusual patterns of sleep, unusual eating behavior such as skipping breakfast and night eating associated with shift work or other life-style disruptions of the day-night cycle may have a major pathological impact on the development of diabetes mellitus. In fact, two BMAL-1 haplotypes have recently been shown to be associated with type 2 diabetes and hypertension in a genetic association study. ${ }^{49}$

\section{Shift work}

In the manufacturing industry worldwide, $20 \%-25 \%$ of the employees are involved in shift work. ${ }^{50}$ While there is no precise definition of shift work, most studies classify shift workers as those who regularly work outside the usual daytime shift hours. ${ }^{47}$ Shift work is thought to be associated with several health problems, such as metabolic syndrome, diabetes mellitus, and cardiovascular disease that are possibly partly the result of impaired biological circadian rhythms. ${ }^{50}$
In an early cross-sectional Japanese male study, increased prevalence of diabetes mellitus was reported among shift workers $(2.1 \%$ in shift workers and $0.9 \%$ in daytime workers) (Table 1) ${ }^{51}$ In an 8-year cohort study with Japanese male industrial workers, rotating shift work was associated with a slightly higher risk of diabetes mellitus, but the effect did not reach statistical significance. ${ }^{52}$ In addition, in a study of 2,860 Japanese male factory workers, the relative risk of diabetes mellitus for shift workers was 1.3 1.7, but these values also were not statistically significant. ${ }^{53}$ While the early research on Japanese male subjects was inconclusive, in a study of female workers on rotating night-shift work, there was a significant association with type 2 diabetes mellitus in an age-adjusted model, although the authors state that the association was mediated by body weight. ${ }^{54}$

Furthermore, in a recent two-cohort study of female workers in the Nurse's Health Study, rotating night-shift work was associated with a modestly increased risk of type 2 diabetes mellitus. ${ }^{55}$ In a prospective cohort study of middleaged Swedish men and women with 8-10 years of follow-up, there was a positive association between shift work and type 2 diabetes mellitus in women (odds ratio [OR] 2.2 [95\% confidence interval $\{\mathrm{CI}\} 1.0-4.7\}$ adjusted for age, education, and psychological distress). This association also seems to be mediated by body mass index (BMI). ${ }^{56}$ There was no association between shift work and type 2 diabetes in men 
Table I Summary of the behavioral aspects of circadian rhythm in relation to development of type 2 diabetes mellitus

\begin{tabular}{|c|c|c|c|c|}
\hline Authors & $\begin{array}{l}\text { Year of } \\
\text { publication }\end{array}$ & Methods & Main results & Ref no \\
\hline \multicolumn{5}{|l|}{ Shift work } \\
\hline Mikuni et al & 1983 & $\begin{array}{l}\text { Japanese } 9,000 \text { males age-and weight- } \\
\text { adjusted prevalence }\end{array}$ & $\begin{array}{l}\text { Prevalence of diabetes } \\
2.1 \% \text { in all three shifts } \\
0.9 \% \text { in only day shifts }\end{array}$ & 51 \\
\hline $\begin{array}{l}\text { Kawakami } \\
\text { et al }\end{array}$ & 1999 & $\begin{array}{l}\text { Japanese 2,194 males } 8 \text {-year } \\
\text { prospective cohort study } \\
\text { occurrence of NIDDM } \\
\text { Diabetes criteria WHO }\end{array}$ & $\begin{array}{l}\text { Age adjusted incidence per } \\
\text { I,000 person years } \\
\text { Rotating shift } 2.04 \\
\text { Day only } 1.90\end{array}$ & 52 \\
\hline $\begin{array}{l}\text { Morikawa } \\
\text { et al }\end{array}$ & 2005 & $\begin{array}{l}\text { Japanese } 2,860 \text { males } 8 \text {-year } \\
\text { prospective cohort study occurrence } \\
\text { of diabetes } \mathrm{HbA}_{\mathrm{Ic}} 5.7 \%<\end{array}$ & $\begin{array}{l}\text { Diabetes incidence rate of } \\
4.4 \mathrm{I} / \mathrm{I}, 000 \text { person years } \\
\text { relative risk of diabetes mellitus } \\
\text { two-shift I.73. Three-shift } 1.33\end{array}$ & 53 \\
\hline $\begin{array}{l}\text { Kroenke } \\
\text { et al }\end{array}$ & 2007 & $\begin{array}{l}62,574 \text { US women } 94 \% \text { White } \\
6 \text {-year prospective cohort study } \\
\text { Nurses' Health Study II surveys } \\
\text { ascertainment of type } 2 \text { diabetes }\end{array}$ & $\begin{array}{l}\text { Duration of rotating shift } \\
\text { Age adjusted relative risk } \\
5-<10 \text { years } 1.59,10 \text { years } 1.64 \\
\text { Multivariate-adjusted model } 2 \\
\text { adjusted for BMI } \\
5-<10 \text { years } I .14,10 \text { years } 0.98\end{array}$ & 54 \\
\hline Pan et al & 2011 & $\begin{array}{l}69,269 \text { women aged } 42-67 \text { in } \\
\text { Nurses' Health Study I (NHS I) } \\
107,9 \text { I } 5 \text { women aged } 25-42 \text { in } \\
\text { NHS II I8-20 years cohort study }\end{array}$ & $\begin{array}{l}\text { Pooled hazard ratios participants } \\
\text { with }>20 \text { years of shift work } I .58 \\
(P<0.00 \text { I }) \text { adjusted for updated } \\
\text { BMI participants with }>20 \text { years } \\
\text { I.24 }(P<0.00 \text { I })\end{array}$ & 55 \\
\hline $\begin{array}{l}\text { Erikson } \\
\text { et al }\end{array}$ & 2013 & $\begin{array}{l}3,205 \text { women and } 2,227 \text { men aged } \\
35-56 \text { years } 8-10 \text { years population- } \\
\text { based cohort study baseline normal } \\
\text { OGTT }\end{array}$ & $\begin{array}{l}\text { Odds ratio for shift work in women } \\
\text { Age adjusted } 2.3 \text {, multi-factor adjusted } 1.9 \\
\text { Odds ratio for shift work in men } \\
\text { Age adjusted } 0.9, \text { multi factor adjusted } 0.8\end{array}$ & 56 \\
\hline Eating beh & & & & \\
\hline $\begin{array}{l}\text { Keski- } \\
\text { Rahkonen }\end{array}$ & 2003 & $\begin{array}{l}\text { Five birth cohorts of adolescent twins } \\
\text { and their parents I6-year-old girls and } \\
\text { boys }(n=5,448) \text { and their parents }(n=4,660)\end{array}$ & $\begin{array}{l}\text { Adjusted odds ratios for BMI } 25 \text { or more } \\
\text { Breakfast a few times a week: I.4I } \\
\text { Breakfast once a week or less often: } 2.00\end{array}$ & 58 \\
\hline Cho et al & 2003 & NHANES III & $\begin{array}{l}\text { Breakfast skippers and meat and egg eaters had } \\
\text { higher BMI }\end{array}$ & 59 \\
\hline $\begin{array}{l}\text { Niemeir } \\
\text { et al }\end{array}$ & 2006 & $\begin{array}{l}\text { 9,9I9 adolescents in Waves II } \\
\text { (age II-2I) and III (age I8-27) of } \\
\text { the National Longitudinal Study of } \\
\text { Adolescent Health }\end{array}$ & $\begin{array}{l}\text { Fewer days of breakfast consumption at } \\
\text { Wave II and decreases in breakfast } \\
\text { consumption between Waves II and III } \\
\text { predicted increased BMI at Wave III }\end{array}$ & 60 \\
\hline $\begin{array}{l}\text { Odegaard } \\
\text { et al }\end{array}$ & 2013 & $\begin{array}{l}\text { 3,598 participants from the } \\
\text { community-based Coronary Artery } \\
\text { Risk Development in Young Adults } \\
\text { (CARDIA) study }\end{array}$ & $\begin{array}{l}\text { Eating breakfast daily gained } 1.9 \mathrm{~kg} \text { less } \\
\text { weight over } \mathrm{I} 8 \text { years }(P=0.00 \mathrm{I}) \\
\text { Hazard ratio for type } 2 \text { diabetes was } \\
0.8 \mathrm{I}(0.63-\mathrm{I} .05)\end{array}$ & 61 \\
\hline Morse et al & 2012 & $\begin{array}{l}7 / 4 \text { tertiary care patients with } \\
\text { type I and } 2 \text { diabetes }\end{array}$ & $\begin{array}{l}\text { Patients with night eating behaviors were } \\
\text { more likely to be obese (odds ratio } 2.6 \text { ) } \\
\text { and to have two or more diabetes } \\
\text { complications (odds ratio } 2.6 \text { ) }\end{array}$ & 63 \\
\hline Sleep loss & & & & \\
\hline $\begin{array}{l}\text { Vgontzas } \\
\text { et al }\end{array}$ & 2004 & $\begin{array}{l}25 \text { young, healthy, normal sleepers } \\
\text { ( } 12 \text { men and I } 3 \text { women), I week of } \\
\text { sleep restriction (for only } 2 \text { hours) }\end{array}$ & $\begin{array}{l}\text { 24-hour secretion of IL- } 6 \text { was increased } \\
\text { by } 0.8 \pm 0.3 \mathrm{pg} / \mathrm{mL}(P<0.05) \text { in both sexes, } \\
\text { TNF was increased only in men }\end{array}$ & 70 \\
\hline Tasali et al & 2008 & $\begin{array}{l}\text { Nine healthy volunteers } \\
\text { (age } 20-3 \text { I years; five men and four } \\
\text { women). Experimental suppression } \\
\text { of slow-wave sleep }\end{array}$ & $\begin{array}{l}\text { Marked decreases in insulin sensitivity } \\
\text { without adequate compensatory } \\
\text { increase in insulin release with increased } \\
\text { diabetes risk }\end{array}$ & 71 \\
\hline Scheer et al & 2009 & $\begin{array}{l}\text { Ten adults ( } 5 \text { female) underwent a } \\
\text { I0-day laboratory protocol I } 2 \text { hours } \\
\text { out of phase from their habitual times }\end{array}$ & $\begin{array}{l}\text { Decreased leptin }(I 7 \%, P<0.00 I) \\
\text { Increased glucose }(6 \%, P<0.00 I) \\
\text { Increased insulin }(22 \%, P=0.006)\end{array}$ & 72 \\
\hline
\end{tabular}

Note: The results are summarized in this table.

Abbreviations: NIDDM, non-insulin dependent diabetes mellitus; WHO, World Health Organization; OGTT, oral glucose tolerance test; NHANES, National Health and Nutrition Examination Survey; BMI, body mass index; IL-6, interleukin 6; TNF, tumor necrosis factor; $\mathrm{HbA}_{\mathrm{Ic}}$, glycated hemoglobin. 
(OR 0.9 [95\% CI 0.4-1.7] adjusted for age, education, and psychological distress). Therefore, shift work may contribute to the development of type 2 diabetes mellitus through obesity, especially in women, but the association may be mediated by obesity, as has also been suggested. ${ }^{57}$

\section{Eating behaviors}

Other problems of 24-hour contemporary life have been postulated and investigated, such as breakfast skipping and night eating. In a population-based study of adolescents and their parents, breakfast skipping was significantly associated with high BMI, not only in adolescents but also in their parents. ${ }^{58}$ According to results from the Third National Health and Examination Survey (NHANES III) study with subjects 18 years or older, those who ate breakfast (especially those eating cooked cereal or quick bread) every day showed lower BMI compared to breakfast skippers. ${ }^{59}$ In a prospective study of adolescents over a period of 5 years, breakfast skipping increased during the transition to adulthood, and was associated with increased weight gain. ${ }^{60}$ Breakfast skipping is thus strongly associated with obesity. Recently, several reports have been published on the risk for type 2 diabetes related to breakfast skipping. In a cohort of 29,206 males in the Health Professionals Follow-Up Study followed for 16 years, breakfast omission was associated with an increased risk of type 2 diabetes mellitus in men even after adjustment for BMI. In addition, in over 18 years of cohort study with young adult men and women, frequent (4-6 days/week) or daily (7 days/week) breakfast consumption was significantly associated with a decreased risk of developing abdominal obesity, obesity, metabolic syndrome, hypertension, and also type 2 diabetes. Actually, in Black women, there was no significant association between breakfast frequency and incidence of type 2 diabetes, possibly because Black women have the highest rate of incidence of type 2 diabetes and the greatest mean level of BMI at baseline relative to the study population. The results are consistent and strongly inversely associated in Black men as well as in White men and women, even after adjustment for BMI. ${ }^{61}$ Breakfast skipping is thus strongly associated with the incidence of type 2 diabetes mellitus. Other eating disorders such as night eating syndrome is also strongly associated with obesity, which strongly affects the clinical outcome of type 2 diabetes. ${ }^{62}$ This disorder is also associated with morning anorexia and evening hyperphagia and insomnia. There is no clear definition of night eating syndrome, but patients who report eating $>25 \%$ of their total daily food intake after regular suppertime (approximately after 9pm) may have night eating syndrome. Such night eating behavior is associated with obesity, higher glycated hemoglobin, and more diabetic complications. ${ }^{63}$

\section{Sleep loss and diabetes}

Sleep disorders (short duration and/or poor quality sleep) may have a profound impact on the development type 2 diabetes and obesity. There are many metabolic cues at the cellular level for clock machinery, but there is no direct evidence of the effects of disruption of the sleep-wake cycle itself on the clock system. However, since a disturbed sleep-wake cycle is often associated with a light phase shift, a changed or shifted light signal itself can regulate the master clock system. The magnitude of the effect of a phase shift or complete disruption of the sleep-wake cycle on human glucose metabolism is unclear. However, there is evidence of the deleterious effects of a shift change in sleep-wake cycles on glucose metabolism.

It has been shown in humans that the molecular clock is linked with sleep ${ }^{64,65}$ in familial advanced sleep phase syndrome. This abnormal sleep syndrome is characterized by early sleep time and early-morning awakening. ${ }^{66}$ In an animal study, wild-type mice prevented from sleeping during the first 6 hours of their normal inactive phase for 5 consecutive days (timed sleep restriction) showed significant transcriptional reprogramming of white adipose tissue, suggestive of increased lipogenesis, together with increased secretion of the adipokine leptin and increased food intake, hallmarks of obesity that are associated with leptin resistance. However, Per $1 / 2$ deficient mice showed blunted effects of this timed sleep restriction on food intake as well as on leptin levels and adipose transcription. ${ }^{67}$ These experimental results suggest a causal relationship between sleep disturbances on clock function and metabolism. In addition, several epidemiological, observational studies indicate that chronic partial sleep loss can increase the risk of obesity and diabetes. ${ }^{68,69}$ Laboratory studies in healthy volunteers have shown that experimental sleep restriction is associated with an adverse impact on glucose homeostasis. Insulin sensitivity decreases rapidly and markedly without adequate compensation in $\beta$ cell function, resulting in an elevated risk of diabetes. ${ }^{68-72}$ In a recent study on sleep restriction, only 2 hours restriction of sleep from 8 hours to 6 hours in young people was associated after 7 days with significant sleepiness, impairment of psychomotor performance, and increased secretion of proinflammatory cytokines such as interleukin 6 (IL-6) and tumor necrosis factor alpha (TNF- $\alpha$ ) which induce insulin resistance. ${ }^{70}$ Although deep non-rapid eye movement sleep, also known as slow-wave sleep, is thought 
to be the most restorative sleep stage, which coincides with hormonal changes that affect glucose regulation, there was a strong correlation between the magnitude of the reduction in short-wave sleep with the decrease in insulin sensitivity. ${ }^{71}$ In addition to epidemiological and observational evidence, a recent experimental study of circadian misalignment in humans, which occurred when subjects ate and slept nearly 12 hours out of phase from their habitual times for a 10-day period, a protocol similar to shift work, showed systemically decreased leptin $(-17 \%)$ and increased glucose $(+6 \%)$ despite increased insulin $(+22 \%)$. Furthermore, circadian misalignment caused three of eight subjects to exhibit postprandial glucose responses in the range typical of a prediabetic state. ${ }^{72}$ As shown by forced manipulation of circadian rhythm, mimicking shift work or jet-lag caused impaired glucose tolerance in some but not all subjects, and hypoleptinemia in most patients. In addition, in a study of 4 hours sleep restriction for 4 days in healthy adults, the insulin concentration required to induce a half-maximal pAkt-tAkt response was nearly 3-fold higher during sleep restriction than during normal sleep, indicating that moderate sleep restriction can also induce an insulin-resistant state. ${ }^{73}$ Recently, circadian typology, which consists of three chronotypes (morning-type [MT], neithertype [NT], evening-type [ET]), have been studied systematically. ${ }^{74}$ About $40 \%$ of the adult population is classified in one of the two extreme groups, while $60 \%$ are NT. The chronotype is defined by biological markers such as sleep-wake cycle, body temperature, cortisol, and melatonin. These chronotypes should be considered for adjustment to shiftwork or jet-lag, as MT reported less sleep problems during day shift while ET reported more problems. This pattern was reversed during night work. Although these chronotypes may well have pathological impacts on type 2 diabetes development and metabolic diseases, more convincing evidence in future study is required to confirm their etiological significance.

\section{Conclusion}

As shown above, evidence that provides new insight into clock function and the pathophysiology of type 2 diabetes is accumulating rapidly. Disruption of circadian rhythms, such as that due to shift work, affects not only body weight and adiposity, but glucose metabolism itself. Since the magnitude of these effects in the present increase seen in the development of type 2 diabetes is obscure, more precise mechanisms and the relative importance of these factors in the development of type 2 diabetes should be investigated. To achieve this goal, it will be necessary to establish methodologies to measure parameters of circadian systems in feeding and glucose and lipid metabolism. ${ }^{75}$ In addition, it is also necessary to analyze the contribution of circadian gene variations in the development of type 2 diabetes. Clinical studies related to the development of type 2 diabetes are also needed to evaluate the health-compromising behaviors that affect circadian disruption with definitions that include chronotype or circadian typology.

According to the currently available data, diabetes patients should be warned about breakfast skipping and night eating syndrome in their diabetes education. Although it is very difficult to control these behaviors for every individual patient with type 2 diabetes, a socio-economical approach such as recommendations regarding the work environment may also be important. Although there is now insufficient evidence to evaluate the impact of these chronophysiological disruptions on the progression or pathophysiology of diabetes precisely, future focused research on these issues can answer these questions.

\section{Disclosure}

The authors have no conflicts of interest to declare.

\section{References}

1. Stephan F, Zucker I. Circadian rhythms in drinking behavior and locomotor activity of rats are eliminated by hypothalamic lesions. Proc Nat Acad Sci U S A. 1972;69(6):1583-1586.

2. Schibler U, Sassone-Corsi P. A web of circadian pacemakers. Cell. 2002;111:919-922.

3. Yang X. A wheel of time: the circadian clock, nuclear receptors, and physiology. Genes Dev. 2010;24(8):741-747.

4. Preitner N, Damiola F, Luis-Lopez-Moliona, et al. The orphan nuclear receptor REV-ERB $\alpha$ controls circadian transcription within the positive limb of the mammalian circadian oscillator. Cell. 2002;110(2):251-260.

5. Liu AC, Tran HG, Zhang EE, Priest AA, Welsh DK, Kay SA. Redundant function of REV-ERB $\alpha$ and $\beta$ and non-essential role for BMAL-1 cycling in transcriptional regulation of intracellular circadian rhythms. PLoS Genet. 2008;4(2):e1000023.

6. Li MD, Ruan HB, Hughes ME, et al. O-GlcNAc signaling entrains the circadian clock by inhibiting BMAL1/CLOCK ubiquitination. Cell Metab. 2013;17(2):303-310.

7. Rutter J, Reick M, Wu LC, McKnight SL. Regulation of clock and NPAS2 DNA binding by the redox state of NAD cofactors. Science. 2001;293(5529):510-514.

8. Ramsey KM, Bass J. Circadian Clocks in fuel harvesting and energy homeostasis. Cold Spring Harb Symp Quant Biol. 2011;76:63-72.

9. Nakahata Y, Sahar S, Astarita G, Kaluzova M, Sassone-Corsi P. Circadian control of the NAD+ salvage pathway by CLOCK-SIRT1. Science. 2009;324(5927):654-657.

10. Ramsey KM, Yoshino J, Brace CS, et al. Circadian clock feedback cycle through NAMPT-mediated NAD+ biosynthesis. Science. 2009;324(5927):651-654.

11. Asher G, Gatfield D, Stratmann M, et al. SIRT1 regulates circadian clock gene expression through PER2 deacetylation. Cell. 2008;134(2): 317-328.

12. Nakahata Y, Kaluzova M, Grimaldi B, et al. The NAD+-dependent deacetylase SIRT1 modulates CLOCK-mediated chromatin remodeling and circadian control. Cell. 2008;134(2):329-340. 
13. Liu C, Li S, Liu T, Borjigin J, Lin JD. Transcriptional coactivator PGC-1 $\alpha$ integrates the mammalian clock and energy metabolism. Nature. 2007:447(7143):477-481.

14. Um JH, Yang S, Yamazaki S, et al. Activation of 5'-AMP-activated kinase with diabetes drug metformin induces casein kinase IE(CKIE)dependent degradation of clock protein mPer2. J Biol Chem. 2007;282(23):20794-20798.

15. Haigis MC, Guarente LP. Mammalian sirtuins - emerging roles in physiology, aging, and calorie restriction. Genes Dev. 2006;20(21): 2913-2921.

16. Dali-Youcef N, Lagouge M, Froelich S, Koehl C, Schoonjans K, Auwerx J. Sirtuins: the 'magnificent seven', function, metabolism and longevity. Ann Med. 2007;39(5):335-345.

17. Rodgers JT, Lerin C, Haas W, Gygi SP, Spiegelman BM, Pulgserver P. Nutrient control of glucose homeostasis through a complex of PGC-1 $\alpha$ and SIRT1. Nature. 2005;434(7029):113-118.

18. Bloomgarden ZT. Insulin resistance concepts. Diabetes Care. 2007;30(5):1320-1326.

19. Lamia KA, Sachdeva UM, DiTacchio L, et al. AMPK regulates the circadian clock by cryptochrome phosphorylation and degradation. Science. 2009;326(5951):437-440.

20. Yang X, Downes M, Yu RT, et al. Nuclear receptor expression links the circadian clock to metabolism. Cell. 2006;126(4):801-810.

21. Yin L, Wu N, Curtin JC, et al. Rev-erbo, a heme sensor that coordinates metabolic and circadian pathways. Science. 2007;318(5857): 1786-1789.

22. Duez H, Staels B. The nuclear receptors Rev-erbs and RORs integrate circadian rhythms and metabolism. Diab Vasc Dis Res. 2008;5(2): $82-88$

23. Sato TK, Panda S, Miraglia LJ, et al. A functional genomics strategy reveals Rora as a component of the mammalian circadian clock. Neuron. 2004;43(4):527-537.

24. Lefebvre P, Chinetti, G Fruchart JC, Staels B. Sorting out the roles of PPAR $\alpha$ in energy metabolism and vascular homeostasis. J Clin Invest. 2006;116(3):571-580.

25. Raghuram S, Stayrook KR, Huang P, et al. Identification of heme as the ligand for the orphan nuclear receptors REV-ERB $\alpha$ and REV-ERB $\beta$. Nat Struct Mol Biol. 2007;14(12):1207-1213.

26. Handschin C, et al. Nutritional regulation of hepatic heme biosynthesis and porphyria through PGC-1 $\alpha$. Cell. 2005;122(4):505-515.

27. Chen JJ, London IM. Hemin enhances the differentiation of mouse 3T3 cells to adipocytes. Cell. 1981;26(1 Pt 1):117-122.

28. Kohsaka A, Laposky AD, Ramsey KM, et al. High-fat diet disrupts behavioral and molecular circadian rhythms in mice. Cell Metab. 2007;6(5):414-421.

29. Polonsky K, Given BD, Hirsch LJ, et al. Abnormal patterns of insulin secretion in non-insulin-dependent diabetes mellitus. $N$ Engl $J$ Med. 1988;318(19):1231-1239.

30. Peschke E, Peschke D. Evidence for a circadian rhythm of insulin release from perifused rat pancreatic islets. Diabetologia. 1998;41(9):1085-1092.

31. Polonsky K, Given BD, Van Cauter E. Twenty-four-hour profiles of pulsatile patterns of insulin secretion in normal and obese subjects. J Clin Invest. 1988;81(2):442-448.

32. TurekFW, Joshu C, Kohsaka A, et al. Obesity and metabolic syndrome in circadian clock mutant mice. Science. 2005;308(5724):1043-1045.

33. Ikeda H, Yong Q, Kurose T, et al. Clock gene defect disrupts light-dependency of autonomic nerve activity. Biochem Biophys Res Commun. 2007;364(3):457-463.

34. Zhang EE, Liu Y, Dentin R, et al. Cryptochrome mediates circadian regulation of cAMP signaling and hepatic gluconeogenesis. Nat Med. 2010;16(10):1152-1156.

35. Marcheva B, Ramsey KM, Buhr ED, et al. Disruption of the clock components CLOCK and BMAL1 leads to hypoinsulinaemia and diabetes. Nature. 2010;466(7306):627-631.

36. Gale JE, Cox HI, Qian J, et al. Disruption of circadian rhythms accelerates development of diabetes through pancreatic $\beta$-cell loss and dysfunction. J Biol Rhythms. 2011;26(5):423-433.
37. Qian J, Block GD, Colwell CS, Matveyenko AV. Consequences of exposure to light at Night on the pancreatic Islet circadian clock and function in rats. Diabetes. 2013;62:3469-3478.

38. Shi SQ, Ansari TS, McGuinness OP, Wasserman DH, Johnson CH. Circadian disruption leads to insulin resistance and obesity. Curr Biol. 2013;23(5):372-381.

39. Ruiter M, LaFleur SE, Heijningen C, Vliet J, Kalsbeek A, Buijs RM. The daily rhythm in plasma glucagon concentrations in the rat is modulated by the biological clock and by feeding behavior. Diabetes. 2003;52(7):1709-1715.

40. Turton MB, Deegan T. Circadian variations of plasma catecholamine, cortisol and immunoreactive insulin concentrations in supine subjects. Clin Chim Acta. 1974;55(3):389-397.

41. Dickmeis T. Glucocorticoids and the circadian clock. $J$ Endocrinol. 2009;200(1):3-22.

42. Bass J, Takahashi JS. Circadian integration of metabolism and energetics. Science. 2010;330(6009):1349-1354.

43. Kalsbeek A, Foppen E, Schalij I, et al. Circadian control of the daily plasma glucose rhythm: an interplay of GABA and glutamate. PLoS One. 2008;3(9):e3194.

44. Arble DM, Bass J, Laposky AD, Vitaterna1 MH, Turek FW. Circadian timing of food intake contributes to weight gain. Obesity (Silver Spring). 2009;17(11):2100-2102.

45. Bray MS, Tsai JY, Villegas-Montoya C. Time-of-day-dependent dietary fat consumption influences multiple cardiometabolic syndrome parameters in mice. Int J Obes (Lond). 2010;34(11):1589-1598.

46. Wu T, Sun L, ZhuGe F, et al. Differential roles of breakfast and supper in rats of a daily three-meal schedule upon circadian regulation and physiology. Chronobiol Int. 2011;28(10):890-903.

47. Kurose T, Yabe D, Inagaki N. Circadian rhythm and diabetes. J Diabetes Investig. 2011;2(3):176-177.

48. Huang W, Ramsey KM, Marcheva B, Bass J. Circadian rhythms, sleep, and metabolism. J Clin Invest. 2011;121(6):2133-2141.

49. Woon PY, Kaisaki PJ, Braganc J, et al. Aryl hydrocarbon receptor nuclear translocator-like (BMAL1) is associated with susceptibility to hypertension and type 2 diabetes. Proc Natl Acad Sci U S A. 2007;104(36):14412-14417.

50. Szosland D. Shift work and metabolic syndrome, diabetes mellitus and ischemic heart disease. Int J Occup Med Environ Health. 2010;23(3):287-291.

51. Mikuni E, Ohishi T, Hayashi K, Miyamura K. Glucose intolerance in an employed population. Tohoku J Exp Med. 1983;141 Suppl:251-256.

52. Kawakami N, Araki S, Takatsuka N, Shimizu H, Ishibashi H. Overtime, psychosocial working conditions, and occurrence of noninsulin dependent diabetes mellitus in Japanese men. $J$ Epidemiol Community Health. 1999;53(6):359-363.

53. Morikawa Y, Nakagawa H, Miura K, et al. Shift work and the risk of diabetes mellitus among Japanese male factory workers. Scand J Work Environ Health. 2005;31(3):179-183.

54. Kroenke CH, Spiegelman D, Manson JA, Schernhammer ES, Colditz GA, Kawachi I. Work characteristics and incidence of type 2 diabetes in women. Am J Epidemiol. 2007;165(2):175-183.

55. Pan A, Schernhammer ES, Sun Q, Hu FB. Rotating night shift work and risk of type 2 diabetes: two prospective cohort studies in women. PLoS Med. 2011;8(12):e1001141.

56. Eriksson AK, Van Den Donk M, Ding AH, Östenson CG. Work stress, sense of coherence, and risk of type 2 diabetes in a prospective study of middleaged Swedish men and women. Diabetes Care. 2013;36(9):2683-2689.

57. Antunes LC, Levandovski R, Dantas G, Caumo W, Hidalgo MP. Obesity and shift work: chronobiological aspects. Nutr Res Rev. 2010;23(1):155-168.

58. Keski-Rahkonen A, Kaprio J, Rissanen A, Virkkunen M, Rose RJ. Breakfast skipping and health-compromising behaviors in adolescents and adults. Eur J Clin Nutr. 2003;57(7):842-845.

59. Cho S, Dietrich M, Brown CJP, Clark CA, Block G. The effect of breakfast type on total daily energy intake and body mass index: results from the third National Health and Nutrition Examination Survey (NHANES III). J Am Coll Nutr. 2003;22(4):296-302. 
60. Niemeir HM, Raynor HA, Lloyd-Richardson EE, Rogers ML, Wing RR. Fast food consumption and breakfast skipping: predictors of weight gain from adolescence to adulthood in a nationally representative sample. $J$ Adolesc Health. 2006;39(6):842-849.

61. Odegaard AO, Jcobs DR, Steffen LM, Horn LV, Ludwig DS, Pereira MA. Breakfast frequency and development of metabolic risk. Diabetes Care. 2013;36(10):3100-3106.

62. Vander Wal JS. Night eating syndrome: a critical review of the literature. Clin Psychol Rev. 2012;32(1):49-59.

63. Morse SA, Paul S. Ciechanowski PS, Katon WJ, Hirsch IB. Isn't this just bedtime snacking? The potential adverse effects of night-eating symptoms on treatment adherence and outcomes in patients with diabetes. Diabetes Care. 2006;29(8):1800-1804.

64. Toh LK, Jones CR, He Y, et al. An hPer2 phosphorylation site mutation in familial advanced sleep phase syndrome. Science. 2001;291(5506): 1040-1043.

65. Xu Y, Padiath QS, Shapiro RE, et al. Functional consequences of a CKIdelta mutation causing familial advanced sleep phase syndrome. Nature. 2005;434(7033):640-644

66. Jones CR, Campbell SS, Zone SE, et al. Familial advanced sleepphase syndrome: A short-period circadian rhythm variant in humans. Nat Med. 1999;5(9):1062-1065.

67. Husse J, Hintze SC, Eichele G, Lehnert E, Oster H. Circadian clock genes Per1 and Per2 regulate the response of metabolism-associated transcripts to sleep disruption. PLoS One. 2012;7(12):e52983.
68. Knutson LK, Van Cauter E. Associations between sleep loss and increased risk of obesity and diabetes. Ann N Y Acad Sci. 2008;1129:287-304.

69. Bass J, Turek FW. Sleepless in America: a pathway to obesity and the metabolic syndrome? Arch Intern Med. 2005;165(1):15-16.

70. Vgontzas AN, Zoumakis E, Bixler EO, et al. Adverse effects of modest sleep restriction on sleepiness, performance, and inflammatory cytokines. J Clin Endocrinol Metab. 2004;89(5):2119-2126.

71. Tasali E, Leproult R, Ehrmann DA, Van Cauter E. Slow-wave sleep and the risk of type 2 diabetes in humans. Proc Natl Acad Sci USA. 2008;105(3):1044-1049.

72. Scheer FAJL, Hiltona MF, Mantzoros CS, Shea SA. Adverse metabolic and cardiovascular consequences of circadian misalignment. Proc Natl Acad Sci U S A. 2009;106(11):4453-4458.

73. Broussard JL, Ehrmann DA, Van Cauter E, Tasali E, Brady MJ. Impaired insulin signaling in human adipocytes after experimental sleep restriction: a randomized, crossover study. Ann Intern Med. 2012;157(8):549-557.

74. Adan A, Archer SN, Hidalgo MP, Milia LD, Natale V, Randler C. Circadian typology: a comprehensive review. Chronobiol Int 2012;29(9):1153-1175.

75. Green CB, Takahashi JS, Bass J. The meter of metabolism. Cell. 2008;134(5):728-742.
ChronoPhysiology and Therapy

\section{Publish your work in this journal}

ChronoPhysiology and Therapy is an international, peer-reviewed, open access journal focusing on research into the cyclic variations and rhythmicity in physiological processes in the body and the research and development and optimal timing of administration of therapeutic targets to achieve improved outcomes and quality of life for the patient. The

\section{Dovepress}

manuscript management system is completely online and includes a very quick and fair peer-review system. Visit http://www.dovepress.com/ testimonials.php to read real quotes from published authors. 